\title{
Pharmacological Therapy of Bronchial Asthma: The Role of Biologicals
}

\author{
Sebastian Heck ${ }^{a}$ Juliane Nguyen ${ }^{c}$ Duc-Dung Le ${ }^{a}$ Robert Bals ${ }^{b}$ \\ Quoc Thai Dinh ${ }^{a, b}$
}

Departments of a Experimental Pneumology and Allergology and ${ }^{b}$ Internal Medicine V, Pneumology, Allergology and Respiratory Critical Care Medicine, Saarland University Faculty of Medicine, Homburg/Saar, Germany; ${ }^{\mathrm{C} D e p a r t m e n t}$ of Pharmaceutical Sciences, School of Pharmacy and Pharmaceutical Sciences, SUNY, Buffalo, N.Y., USA

\author{
Key Words \\ Asthma · Biologicals · Interleukins · Treatment · Tumor \\ necrosis factor . CC chemokine receptor . \\ Granulocyte-macrophage colony-stimulating factor . \\ Chemoattractant receptor-homologous molecule \\ expressed on $\mathrm{T}_{\mathrm{H}} 2$ cells - Macrolides
}

\begin{abstract}
Bronchial asthma is a heterogeneous, complex, chronic inflammatory and obstructive pulmonary disease driven by various pathways to present with different phenotypes. A small proportion of asthmatics (5-10\%) suffer from severe asthma with symptoms that cannot be controlled by guideline therapy with high doses of inhaled steroids plus a second controller, such as long-acting $\beta_{2}$ agonists (LABA) or leukotriene receptor antagonists, or even systemic steroids. The discovery and characterization of the pathways that drive different asthma phenotypes have opened up new therapeutic avenues for asthma treatment. The approval of the humanized anti-lgE antibody omalizumab for the treatment of severe allergic asthma has paved the way for other cytokine-targeting therapies, particularly those targeting interleukin (IL)-4, IL-5, IL-9, IL-13, IL-17, and IL-23 and the epithelium-derived cytokines IL-25, IL-33, and thymic stromal lymphopoietin. Knowledge of the molecular basis of asthma phenotypes has helped, and continues to help, the develop-
\end{abstract}

\section{KARGER 125\%}

() 2016 S. Karger AG, Basel

1018-2438/16/1684-0241\$39.50/0

E-Mail karger@karger.com

www.karger.com/iaa ment of novel biologicals that target a diverse array of phenotype-specific molecular targets in patients suffering from severe asthma. This review summarizes potential therapeutic approaches that are likely to show clinical efficacy in the near future, focusing on biologicals as promising novel therapies for severe asthma.

(c) 2016 S. Karger AG, Basel

\section{Introduction}

Bronchial asthma is a heterogeneous, complex, chronic inflammatory and obstructive pulmonary disease characterized by augmented mucus secretion, airway hyperreactivity, and, in the long term, functional and structural lung tissue alterations [1]. Asthma currently affects an estimated 235 million people worldwide. Most asthmatics are well controlled with asthma guideline therapies. Extrinsic (allergic) asthma is the predominant asthma subtype and usually manifests during childhood, while late-onset asthma is mostly nonallergic [2]. However, a small portion of asthma patients (5-10\%) suffer from severe asthma that is refractory to high doses of inhaled steroids plus a second controller. In the uncontrolled situation, long-acting $\beta_{2}$ agonists (LABA) and/or phosphodiesterase inhibitors and/or long-acting anticholinergics (LAMA) are also used to treat severe asthma. Treatment 
Table 1. New potential drugs in the pipeline for asthma treatment and their target and developmental stage

\begin{tabular}{|c|c|c|c|}
\hline Drug name & Drug target & Developmental stage & Estimated time of market launch \\
\hline Omalizumab & $\operatorname{IgE}$ & EMA and FDA approved & Already launched \\
\hline QGE-031 & $\operatorname{IgE}$ & Clinical phase III & 2019 \\
\hline MEDI-4212 & IgE & Clinical phase I & After 2020 \\
\hline Quilizumab & IgE & Clinical phase II & After 2020 \\
\hline Dupilumab & IL-4Ra & Clinical phase II & After 2020 \\
\hline Pitrakinra & IL-4 Ra & Clinical phase II & NA \\
\hline Pascolizumab & IL-4 & Suspended & - \\
\hline Altrakincept & IL-4 & Suspended & - \\
\hline Mepolizumab & IL-5 & FDA approved & Already launched \\
\hline Reslizumab & IL-5 & Clinical phase II & 2016 \\
\hline Benralizumab & IL-5 Ra & Clinical phase II & After 2020 \\
\hline MEDI-528 & IL-9 & Clinical phase II & NA \\
\hline Tralokinumab & IL-13 & Clinical phase II & $2017-2018$ \\
\hline Lebrikizumab & IL-13 & Clinical phase III & $2017-2018$ \\
\hline QAX-576 & IL-13 & Clinical phase II & After 2020 \\
\hline Anrukinzumab & IL-13 & Clinical phase II & NA \\
\hline ABT-308 & IL-13 & Clinical phase I & NA \\
\hline CNTO 5825 & IL-13 & Clinical phase I & NA \\
\hline GSK679586 & IL-13 & Clinical phase II & NA \\
\hline Brodalumab & IL-17 & Clinical phase II & 2019 \\
\hline Secukinumab & IL-17 & Clinical phase II & NA \\
\hline MT203 & GM-CSF & Clinical phase II & NA \\
\hline Golimumab & TNF- $a$ & Suspended & - \\
\hline Infliximab & TNF- $a$ & Clinical phase II & NA \\
\hline GW766994 & CCR3 & Clinical phase II & NA \\
\hline AMG 761 & CCR4 & Clinical phase II & NA \\
\hline GSK2239633 & CCR4 & Clinical phase II & NA \\
\hline AM211 & CRTH2 & Clinical phase I & NA \\
\hline ARRY-502 & CRTH2 & Clinical phase I & NA \\
\hline QAV 680 & CRTH2 & Clinical phase II & NA \\
\hline Setipiprant & CRTH2 & Clinical phase II & NA \\
\hline RG7185 & CRTH2 & Clinical phase I & NA \\
\hline AMG 853 & CRTH2/DPR & Clinical phase III & NA \\
\hline AZD 1981 & CRTH2/DPR & Clinical phase II & NA \\
\hline AMG 157 & TSLP & Clinical phase II & NA \\
\hline Imatinib & Tyrosine kinases & Clinical phase II & $\mathrm{NA}^{1}$ \\
\hline
\end{tabular}

NA = No estimated time of market launch has been announced; $-=$ there will be no market launch (see text). ${ }^{1}$ Already launched/approved to treat chronic granulocyte leukemia.

with systemic steroids is also often required to control severe asthma, which not only affects the patient's quality of life but can also, in rare cases, cause death. Patients with severe asthma account for over $50 \%$ of the total healthcare costs associated with bronchial asthma [3] due to frequent hospital admissions, the need for emergency services, and high drug consumption. Therefore, there is an urgent need for novel, more effective strategies to treat severe asthma.

Biologicals (or biologics) are mostly genetically synthesized proteins that exert therapeutic effects by activat- ing or inhibiting diverse endogenous target functions. A number of biologicals are currently being used or tested in clinical lung research, and convincing data has been published showing a reduction in asthma exacerbations and improved lung function in asthma patients treated with biologicals. The monoclonal anti-IgE antibody omalizumab was the first biological to be approved [i.e. by the US Food and Drug Administration (FDA) in 2003 and the European Medicine Agency (EMA) in 2005] for the treatment of severe allergic asthma as an alternative to systemic steroids. 
Given the promise of these novel agents and the diverse array of targets, here we review the therapeutic approaches used in patients with bronchial asthma, focusing on biologicals as potential novel therapies for severe asthma (table 1).

\section{The Pathophysiology of Asthma}

Bronchial asthma is a chronic inflammatory and obstructive respiratory disease characterized by mucus hypersecretion, bronchial hyperreactivity and obstruction, and airway remodeling. These pathophysiological features contribute to a progressive loss of lung function $[4,5]$. The major clinical symptoms of bronchial asthma are episodic cough, wheezing, chest tightness, and paroxysmal dyspnea (intermittent shortness of breath). More recently, asthma has been recognized as a heterogeneous, complex disease that presents with different phenotypes $[2,6,7]$.

The inflammatory processes seen in asthma are initiated via interplay between cytokines produced by different cells including B and T lymphocytes, basophils, eosinophils, neutrophils, mast cells, epithelial cells, mesenchymal cells, group 2 innate lymphoid cells (ILC2) [8], and airway neurons. Asthma is also known to have a hereditary etiological component [9], with its development and progression dependent on gene-environment interactions [10].

Dendritic cells (DC) recognize allergens and subsequently process antigen molecules (fig. 1) to expose the antigens on the cell surface for presentation to naive $\mathrm{T}_{\mathrm{H}} 0$ cells. The resulting $\mathrm{T}_{\mathrm{H}} 2$ activation arises from secretion of the key interleukins (IL) IL-4, IL-5, and IL-13, probably from basophils, eosinophils, mast cells, and T cells [11]. $\mathrm{T}_{\mathrm{H}} 2$ cells can release IL-5, which stimulates eosinopoiesis and leads to the recruitment and maturation of eosinophils, leading to severe eosinophilic bronchial asthma. Both IL- 4 and IL-13 result in the production and secretion of IgE by inducing maturation of B lymphocytes to plasma cells [12]. IgE is predominantly membranous, being anchored to the surface of mast cells [13]. Contact between allergens and IgE antibodies initiates intracellular signaling cascades [14] and the secretion of histamine, prostaglandins, cytokines, and other inflammatory mediators [15]. These mediators are proinflammatory and affect a number of cell types including epithelial cells, gland cells and airway smooth muscle cells, leading to bronchoconstriction. Eosinophils, in turn, produce cytokines and leukotrienes, further increasing mucus secretion and bronchoconstriction. $\mathrm{T}_{\mathrm{H}} 2$ cells are also known to release IL- 4 and tumor growth factor (TGF)- $\beta$ to acti- vate IL-9-producing $\mathrm{T}_{\mathrm{H}} 9$ cells [16]. By triggering the proliferation and recruitment of mast cells, IL- 9 results in the release of different inflammatory cytokines. $\mathrm{T}_{\mathrm{H}} 0$ cells activate $\mathrm{T}_{\mathrm{H}} 17$ cells, a population of CD4-positive lymphocytes, via the release of TGF- $\beta$ and IL- 6 and the consequent production and secretion of IL-17A and IL-17F [17-19]. IL-17A and IL-17F induce the migration and recruitment of neutrophils [20] via the secretion of highly potent chemoattractants such as CXC ligand 1 (CXCL1) and CXCL8 (IL-8). These chemoattractants are released by different airway cells such as subepithelial fibroblasts and respiratory bronchial cells [21].

Immune responses to viral respiratory infections are thought to be initiated by the epithelium-derived cytokine thymic stromal lymphopoietin (TSLP). TSLP is a cytokine secreted by mast cells and bronchial epithelium. It mainly acts on DC and initiates the $\mathrm{T}_{\mathrm{H}} 2$-mediated asthma response [22]. TSLP triggers the release of different cytokines of the CC motif chemokine family. The CC chemokine receptors CC chemokine receptor type 3 (CCR3) and CCR4 are G-protein-coupled receptors that are highly expressed in eosinophils and basophils, $\mathrm{T}_{\mathrm{H}} 1$ and $\mathrm{T}_{\mathrm{H}} 2$ cells, and airway epithelia. CCR3 and CCR 4 act as receptors for a variety of chemokines including the eotaxins CCL5, CCL17, and CCL22, which play a role in asthma pathophysiology [23]. There is evidence that CCR3 inhibition may decrease inflammation, and CCR4 is believed to be able to recruit $\mathrm{T}_{\mathrm{H}} 2$ cells to inflammatory sites [24]. CCR4 ligand binding induces the production and release of many cytokines [25] including granulocyte-macrophage colony-stimulating factor (GM-CSF) [26].

Tumor necrosis factor- $\alpha$ (TNF- $\alpha)$ is a cytokine released by macrophages, monocytes, and $\mathrm{CD} 4^{+} \mathrm{T}$ lymphocytes that also plays a role in neutrophilic asthma and promotes different inflammatory effects [25, 27].

Bronchial asthma is characterized not only by inflammatory processes but also by structural lung tissue alterations such as subepithelial fibrosis, increased airway smooth muscle cell proliferation, and extracellular matrix protein deposition. Bronchial membrane thickening decreases lung function by limiting the airflow $[5,25]$.

\section{Bronchial Asthma Phenotypes}

The different phenotypes observed in asthma have been explored in recent years. Although asthma was initially classified into extrinsic and intrinsic types [28], this classification was further characterized as $\mathrm{T}_{\mathrm{H}} 2$ or non$\mathrm{T}_{\mathrm{H}} 2$ phenotypes. The $\mathrm{T}_{\mathrm{H}} 2$-induced phenotype includes 


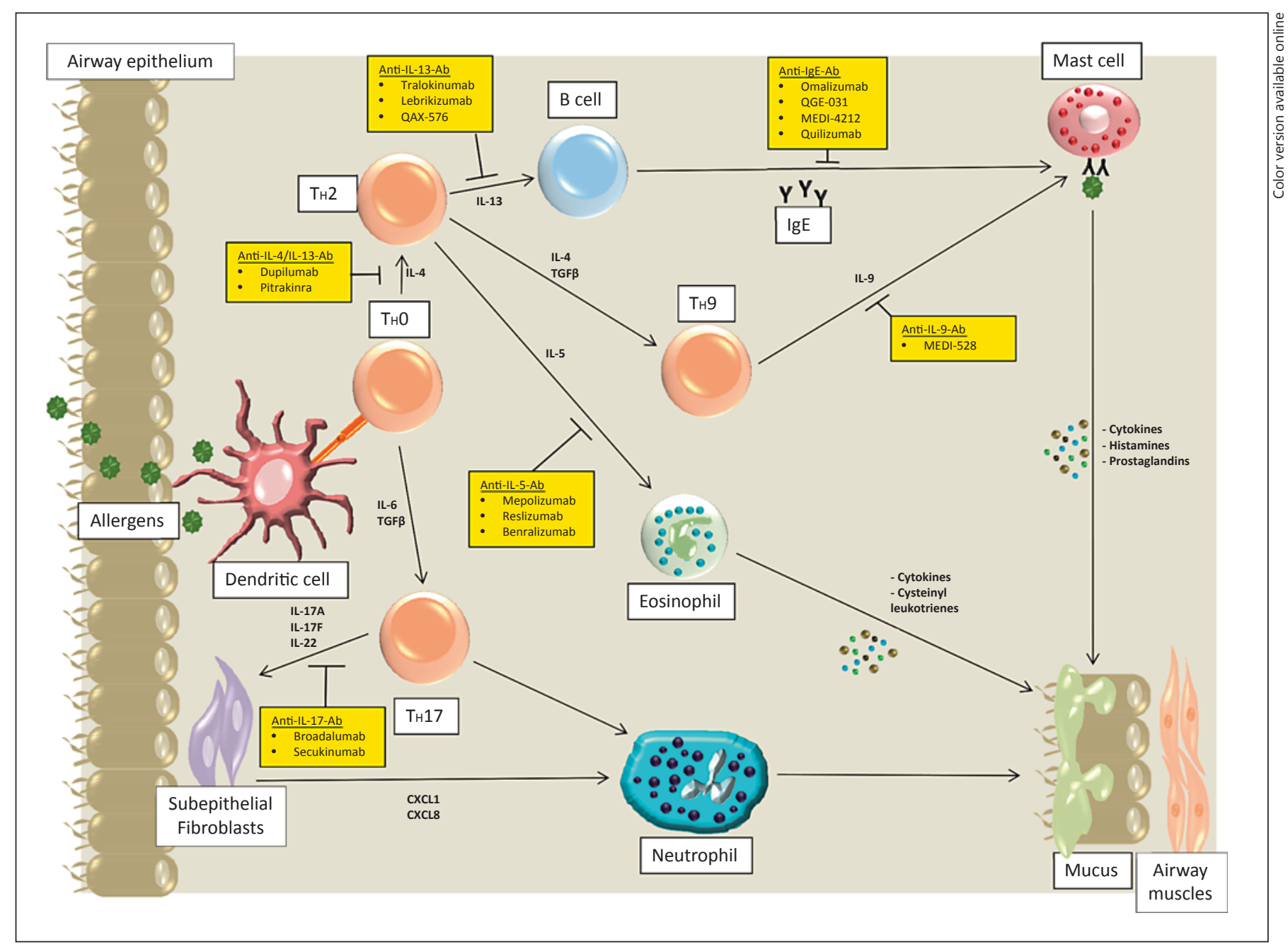

Fig. 1. Key players in the $\mathrm{T}_{\mathrm{H}} 2$-mediated pathomechanism of asthma. DC capture allergens within the cytoplasm, expose them on their surface, and present them to naive $\mathrm{T}_{\mathrm{H}} 0$ cells, which causes the activation of $\mathrm{T}_{\mathrm{H}} 2$ cells and the secretion of IL- 4 and IL-13. Both of these IL activate IgE production and secretion by inducing the maturation of B lymphocytes to plasma cells. The predominantly membranous IgE on mast cells initiates a signal cascade if activated by contact with an allergen. This leads to the secretion of histamines, prostaglandins, cytokines, and other inflammatory mediators. $\mathrm{T}_{\mathrm{H}} 2$ cells also release IL-5, which starts the maturation of eosinophils

early-onset allergic $\mathrm{T}_{\mathrm{H}}$ 2-mediated and late-onset persistent eosinophilic asthma, with a range of severities [2]. Early-onset asthma is often associated with other allergic comorbidities, and its progression can be mild to severe. Late-onset eosinophilic asthma is usually not atopic and is often severely progressive, characterized by increased numbers of sputum and blood eosinophils $[2,29]$. Asthma may be triggered by environmental factors and a genetic predisposition $[30,31]$. The $\mathrm{T}_{\mathrm{H}} 2$-mediated pheno- and finally causes increased mucus secretion in epithelial cells. The expression of IL- 4 and TGF- $\beta$ activates $\mathrm{T}_{\mathrm{H}} 9$ cells, which in turn release IL- 9 and thereby cause the release of different cytokines, histamines, and other inflammatory mediators. The release of TGF- $\beta$ and IL- 6 by $T_{H} 0$ cells activates $T_{H} 17$, which induces the release of IL-17A and IL-17F. Both of these IL initiate the recruitment and expansion of neutrophils via activation of the secretion of chemoattractants (CXCL1 and CXCL8). CXCL1 and CXCL8 are secreted by different cellular components of lung tissue, such as subepithelial fibroblasts and respiratory bronchial cells.

type also includes exercise-induced asthma (EIA), in which symptoms normally occur during and/or after physical activity and increased dry and cold conditions [2]. Asthma symptoms are often relatively mild in EIA patients, although both high and low levels of eosinophilic inflammation have been reported in EIA [32].

Non- $\mathrm{T}_{\mathrm{H}} 2$-mediated asthma is also divided into different subtypes, i.e. women with late-onset asthma, obesityrelated asthma, smoking-associated asthma, neutrophilic 
Table 2. Asthma classification and therapy: level of severity, associated symptoms, and suggested pharmacotherapy (GINA modified)

\begin{tabular}{|c|c|c|}
\hline 1 (intermittent) & $\begin{array}{l}<1 \text { daytime and } 2 \text { nighttime symptoms/week } \\
\mathrm{FEV}_{1} \text { and } \mathrm{PEF} \geq 80 \% \\
\text { Diurnal variability of } \mathrm{PEF}<20 \%\end{array}$ & RABA if needed \\
\hline 2 (low-grade, persistent) & $\begin{array}{l}\text { Same but stronger symptoms than in level } 1 \\
\text { More restrictions in physical activity and sleep } \\
\text { Diurnal variability of PEF between } 20 \text { and 30\% }\end{array}$ & $\begin{array}{l}\text { Low-dose ICS; alternatively, } \\
\text { LTRA (montelukast) }\end{array}$ \\
\hline 3 (moderate, persistent) & $\begin{array}{l}\text { Daily occurring symptoms } \\
>1 \text { nighttime symptom } \\
\text { FEV and PEF of } 60-80 \% \\
\text { Diurnal variability of PEF }>30 \%\end{array}$ & $\begin{array}{l}\text { Middle-dose ICS or low-dose ICS } \\
\text { plus LABA }\end{array}$ \\
\hline 4 (high-grade, persistent) & $\begin{array}{l}\text { Persistent day-to-day symptoms; } \\
\text { Many exacerbations at day- and nighttime; } \\
\text { High negative impact on physical activities } \\
\text { FEV and PEF } \leq 60 \% \\
\text { Diurnal variability of PEF }>30 \%\end{array}$ & Middle-to-high-dose ICS plus LABA \\
\hline $\begin{array}{l}5 \text { (uncontrolled, high-grade, } \\
\text { persistent) }\end{array}$ & $\begin{array}{l}\text { Same but stronger symptoms than in level of } \\
\text { severity } 4\end{array}$ & $\begin{array}{l}\text { Oral corticosteroids; monoclonal } \\
\text { antibodies in IgE-mediated asthma }\end{array}$ \\
\hline
\end{tabular}

$\mathrm{RABA}=$ Rapid-acting $\beta_{2}$ agonists; LTRA = leukotriene receptor antagonist.

asthma, and smooth muscle-mediated, paucigranulocytic asthma [2]. Although these phenotypes represent a substantial proportion of all asthmatics, little is known about their onset [2]. Obesity-related asthma is one of two non$\mathrm{T}_{\mathrm{H}} 2$-related eosinophilic asthma phenotypes. Obesity has a negative effect on lung function, and obese patients are more susceptible to gastroesophageal reflux, chest tightness, and hypoventilation; therefore, asthma may be misdiagnosed in obese patients. Neutrophil-related asthma is another non- $\mathrm{T}_{\mathrm{H}} 2$-related asthma subtype that has yet to be fully characterized [33]. There is evidence that $\mathrm{T}_{\mathrm{H}} 17$ cells may contribute to this neutrophil-related asthma by promoting neutrophilic inflammation. $\mathrm{T}_{\mathrm{H}} 17$ cells release IL-17, a major neutrophil chemoattractant, into the airways [34], and it has been shown that IL-17A and IL-17F levels are associated with asthma severity and an increase in neutrophilic inflammation [17].

\section{Current Pharmacotherapy}

According to the Global Initiative for Asthma (GINA), asthmatics should receive low- to high-dose inhaled steroids alone or in combination with other controllers such as LABA and/or leukotriene receptor antagonists (montelukast) and/or theophylline. Additionally, the long-act-

Pharmacological Therapy of Bronchial Asthma ing muscarinic receptor antagonist tiotropium is recommended for the treatment of severe asthma. Systemic steroids are also often needed in patients with severe asthma. The first biological licensed for asthma is an anti-IgE agent (omalizumab), which is recommended as the preferred controller for patients with severe perennial allergic asthma and may be a suitable alternative treatment to systemic steroids (table 2).

\section{Anti-IgE Therapy}

IgE levels are often increased in allergic asthmatics and they are sometimes associated with allergic symptoms [35]. To significantly reduce IgE-induced symptoms, monoclonal anti-IgE antibodies have been recommended for the treatment of severe allergic asthma. Anti-IgE antibodies can bind free serous $\operatorname{IgE}$ and membranous $\operatorname{IgE}$ at the surface of mast cells and B lymphocytes [36].

Omalizumab binds free IgE with a high affinity by interacting with its $\mathrm{C} \varepsilon 3$ domain [37], thereby reducing asthma exacerbations [38]. Moreover, omalizumab reduces the expression of FceRI on basophils and DC [39]. IgE binding and the reduction in expressed FceRI leads to inhibition of further interactions with ligands and deactivation of signaling cascades. The reduced interaction be- 
tween IgE and FceRI avoids allergen-induced degranulation. As well as reducing circulating IgE levels, new IgE production can be limited or prevented [40]. Furthermore, inhibition of IgE-FceRI binding on DC reduces antigen presentation to $\mathrm{T}$ lymphocytes.

However, omalizumab use is bound by specific clinical criteria. Apart from being approved only for patients with severe asthma (level 5), patients need to: (a) have a forced expiratory volume in $1 \mathrm{~s}\left(\mathrm{FEV}_{1}\right)$ under $80 \%$, (b) be prick test or radioallergosorbent test positive for a perennial inhalation allergen (e.g. mold or house dust), (c) have a serous IgE level between 30 and 1,500 IE/ml, and (d) not weigh over $150 \mathrm{~kg}$. Omalizumab side effects include pruritus, headache, syncope, paresthesia, and anaphylaxis, which could ultimately be lethal due to anaphylactic shock, but, in general, the drug is well tolerated [41]. Based on a study to evaluate its postlaunch safety [42], a higher risk of suffering from thrombotic events caused by the therapy with omalizumab was reported.

Ligelizumab (QGE-031; Novartis) is a humanized monoclonal anti-IgE antibody currently in phase III clinical trials. It binds with a higher affinity to IgE than omalizumab, and analyses have shown an almost 50-fold increased binding affinity to human IgE compared to omalizumab [43]. Ligelizumab suppresses free $\operatorname{IgE}$ more rapidly and to a greater extent and also significantly reduces the wheal diameter in skin prick tests compared to placebo and omalizumab [44]. Ligelizumab is suggested for the treatment of IgE-induced diseases like severe allergic asthma and atopic dermatitis.

MEDI-4212 (AstraZeneca) is also an antibody directed against human IgE that inhibits IgE-FceRI binding and IgE-CD23 binding. Due to its strong inhibitory effect on IgE-FceRI binding, MEDI-4212 is specific for the treatment of asthma patients with high circulating IgE.

Quilizumab (anti-M1 prime mAb; Roche) is a humanized monoclonal antibody currently in phase II clinical trials. Quilizumab binds the M1 prime domain of membranous IgE, thus preventing the differentiation of B lymphocytes into IgE-producing plasma cells. Based on phase II clinical trial data, quilizumab may be suitable for the treatment of moderate to severe asthma. The drug has been retracted due to a lack of effect.

\section{Anti-IL-5 Therapy}

IL-5, which is secreted mainly by $\mathrm{T}_{\mathrm{H}} 2$ cells but also in smaller amounts by eosinophils and mast cells, plays a key role in the immune reaction by activating eosino- phils. The IL-5 receptor is the single interaction partner of IL-5, but it also works in synergy with other signaling molecules such as chemokines, eotaxins, and IL-4 and IL-13 to drive the eosinophilic immune response [45]. The IL-5 receptor (IL-5R) is composed of $\alpha$ and $\beta$ subunits $[45,46]$. The $\alpha$ subunit binds peptides and the $\beta$ subunit is the signal transduction domain. The IL-5 receptor is expressed on the surface of eosinophils, Eos progenitors (CD34+; eosinophil progenitor cells), mast cells, and basophils $[45,46]$. The intracellular signal is mainly transduced via the Janus kinase-activated 2 (JAK2)/signal transducer and activator of transcription 3 (STAT-3) pathway [46].

Mepolizumab, a humanized monoclonal anti-IL-5 antibody, reduced eosinophils in patients suffering from eosinophilic asthma, significantly lowering the number of eosinophils in circulation and in the lung and bone marrow [47]. Asthma exacerbations were distinctly decreased $[48,49]$, and side effects have not been observed to the date of reporting [50]. Mepolizumab has just been approved for asthma therapy by the FDA (11/2015) and the approval from the EMA is launched.

Another humanized monoclonal anti-IL-5 antibody, reslizumab, has been evaluated for the treatment of severe eosinophilic asthma [51]. Animal studies revealed a 75\% decrease in eosinophil accumulation, and current clinical trials have shown a nonsignificant decrease in the asthma exacerbation rate [52].

Benralizumab also belongs to the group of monoclonal anti-IL-5 antibodies, and it binds IL-5Ra with a high affinity even in the presence of slight conformational changes of the epitope. This leads to interruption of IL-5R-mediated signal transduction and inhibition of IL-5R-dependent cell proliferation [53]. There is evidence to suggest that benralizumab may be effective in both serum and tissue [54], perhaps increasing the ultimate clinical significance of this drug. Benralizumab is afucosylated, which improves the antibody dependent cell-mediated cytotoxicity [55].

\section{Drugs Targeting IL-9}

IL-9, derived from $\mathrm{T}_{\mathrm{H}} 2$ and $\mathrm{T}_{\mathrm{H}} 9$ cells, and the IL-9 receptor (IL-9R) are overexpressed in the airways of asthmatics [56]. This leads to eosinophilic inflammation associated with airway hyperresponsiveness (AHR), mucus hyperplasia, mast cell proliferation [57], and augmented expression of IgE and other $\mathrm{T}_{\mathrm{H}} 2$-related cytokines [21]. Additionally, IL-9 triggers IL-13 secretion. 
MEDI-528 is a humanized monoclonal anti-IL-9 antibody currently in phase II trials. Clinical trial results have differed; when MEDI-528 was used in addition to standard asthma medication, there were no significant effects on asthma exacerbation rates, asthma control questionnaire-6 (ACQ-6) scores, or $\mathrm{FEV}_{1}$ compared to placebo controls [58]. In patients with mild to moderate asthma, there are some data to suggest that MEDI-528 might have clinical relevance. The two studies performed to the date of reporting indicate an improved quality of life with the use of this agent with respect to asthma symptoms and exacerbations [59].

\section{Drugs Targeting IL-13}

IL-13 plays a key role in the initiation and maintenance of inflammation in bronchial asthma, where it exerts the following functions: (i) initiation of the IgM-toIgE isotype switch in B lymphocytes [60, 61], (ii) mediation of the activation and proliferation of mast cells [62] and smooth muscle cells [63], and (iii) triggering of the adhesion of eosinophils to vascular endothelial cells [64]. In contrast to IL-4, which is able to mediate its effects via the type I IL-4R (IL-4a and IL-4) or the type II IL-4R, evidence suggests that IL-13 binds solely to the type II IL$4 \mathrm{R}$, which consists of 2 subunits, i.e. the IL-13R- $\alpha 1$ and IL-4R- $\alpha$ chains. Therefore, it is thought that an IL-4-independent IL-13 signaling pathway exists [65].

Tralokinumab is a humanized anti-IL-13 monoclonal antibody currently in phase II trials. Furthermore, experiments in tralokinumab-treated mice showed that AHR and eosinophilic influx are reduced in an allergic airway inflammation model [66].

In a randomized multicenter study, lebrikizumab, which blocks IL-13, significantly improved lung function in asthmatic patients. The drug seemed to have a marked differential impact depending on the asthma phenotype, being particularly effective in $\mathrm{T}_{\mathrm{H}} 2$ phenotypes with high serous periostin levels.

Other anti-IL-13 agents include: QAX-576, an IL-13 antibody, which is being tested in an early-stage study of patients with moderate to severe asthma; anrukinzumab, a humanized monoclonal anti-IL-13 antibody currently in phase II clinical trials and showing significant improvements in patients with mild atopic asthma [25]; ABT-308, a high-affinity anti-human IL-13 antibody that prevents IL-13 binding to the IL-13R 1 and IL-13Ra2 subunits, currently in phase I trials after showing significant effects in mice; CNTO 5825, a human monoclonal
anti-IL-13 antibody that has exhibited good safety and tolerability profiles in phase I clinical trials [67], and GSK 679586, a humanized anti-IL-13 IgG1 monoclonal antibody that has currently completed phase II testing. GSK 679586 showed dose-dependent pharmacological activity in a randomized, placebo-controlled phase I dose escalation study [68].

\section{Drugs Targeting IL-4}

IL-4 and IL-13 share one receptor, i.e. the IL-4 a-subunit. The mechanism via which IL- 13 is activated by IL-4R is not fully understood [69]. It is known, however, that IL- 4 contributes to the pathomechanism of asthma by initiating $\mathrm{T}_{\mathrm{H}} 2$ differentiation, isotype switching of $\mathrm{B}$ lymphocytes during IgE synthesis, mast cell development, eosinophil recruitment, and mucus metaplasia [21]. Moreover, IL-4 is a key player in fibronectin and collagen synthesis [70], which ultimately leads to airway remodeling.

Dupilumab, a human monoclonal antibody, is directed against IL-4Ra. IL-4 and IL-13 blockade directly affects IL-4R and indirectly affects downstream IL-13R pathways since IL-13 also binds to IL-4R $\alpha$. A clinical trial in moderate to severe asthmatics revealed a reduced risk of exacerbations and a significant improvement in most lung function tests [71].

Pitrakinra is a recombinant human protein that acts as an IL-4 and IL-13 antagonist by competitively blocking IL-4Ra, thereby affecting both pathways simultaneously. By inhibiting IL-4 and IL-13, pitrakinra inhibits $\mathrm{T}_{\mathrm{H}} 2$-mediated immune responses [51]. Clinical and preclinical animal studies have shown that pitrakinra is significantly more effective on AHR when inhaled rather than subcutaneously injected [72].

Pascolizumab is a humanized anti-IL-4 antibody that inhibits both upstream and downstream $\mathrm{T}_{\mathrm{H}} 2$ pathway events [73]. Pascolizumab was very well tolerated in a phase I trial in adult patients with mild to moderate asthma, but it lacked clinical efficacy in a large-scale multidose phase II trial in steroid-naive patients with symptomatic asthma [25].

Altrakincept, a soluble recombinant human IL-4 receptor, contains the IL-4Ra chain but lacks the other domains. Thus, it cannot activate downstream cascades. IL-4 binds to the IL-4Ra domain of altrakincept and is therefore removed from the circulation. However, phase II clinical trials revealed no significant improvement in lung function and asthma symptoms [74] with altrakincept and no new studies are currently planned. 


\section{Drugs Targeting IL-17}

IL-17 is secreted by $\mathrm{T}_{\mathrm{H}} 17$ cells and plays an important role in airway remodeling and neutrophilic inflammation. IL-17 molecules comprise several subtypes, i.e. IL17A, IL-17B, IL-17C, IL-17E (IL-25), and IL-17F [17]. IL-17 appears to be a promising drug target in asthma, with 2 antibodies in particular, i.e. broadalumab and secukinumab, showing promise. However, their therapeutic effect, tolerability, and safety need to be confirmed in further clinical evaluations.

Brodalumab is a human IL-17-specific monoclonal antibody in phase II clinical trials of patients with severe asthma not adequately controlled by inhaled corticosteroids and LABA. Secukinumab targets IL-17A and is in phase II trials. It is suggested for use in patients with severe asthma that cannot be controlled with inhaled corticosteroids and LABA.

\section{Drugs Targeting GM-CSF}

GM-CSF is a glycoprotein that plays a role in the transduction of inflammatory reactions. GM-CSF is generated with other proinflammatory mediators, mainly by epithelial cells but also by fibroblasts, macrophages, mast cells, and natural killer cells; it is then released into the circulation [75]. This leads to activation and differentiation of various cell types that induce airway inflammation with resulting damage to the airway epithelium [76]. Because of the role of GM-CSF during inflammatory events, it may represent a potential future drug target for the treatment of asthma [77].

\section{Drugs Targeting TNF-a}

TNF- $\alpha$, a proinflammatory innate cytokine secreted by macrophages, mast cells, $\mathrm{T}_{\mathrm{H}} 1$ lymphocytes, and many other cell types, is overexpressed in the lung tissue of asthmatics and stimulates respiratory smooth muscle [25]. During airway inflammation, TNF- $\alpha$ recruits eosinophils and neutrophils [27]. Despite several controversies (regarding the assertion that blocking TNF- $\alpha$ may lead to a higher risk of infection and cancer), clinical studies with infliximab, etanercept, and golimumab have been undertaken.

The human-murine chimeric monoclonal anti-TNF- $\alpha$ antibody infliximab significantly improved lung function parameters (e.g. peak expiratory flow) and exacerbations in patients with moderate asthma [78]. Etanercept is a recom- binant protein that binds both TNF- $\alpha$ and lymphotoxin (TNF- $\beta$ ) with a high affinity; however, it showed no significant positive effects in a randomized, double-blind, placebo-controlled phase II trial [79]. Golimumab is an antiTNF- $\alpha$ antibody that should have been a candidate biological for severe asthma. However, a large multicenter study revealed side effects including infection, pneumonia, tuberculosis, and malignancy (breast cancer and B-cell lymphoma) [80]. Understandably, the research community subsequently withdrew from further anti-TNF- $a$ trials.

\section{Drugs Targeting CCR3 and CCR4}

Chemokines play a pivotal role in respiratory inflammation [81]. The CC chemokine receptors CC chemokine receptor type 3 (CCR3) and CCR4 are G-proteincoupled proteins that are highly expressed in eosinophils, basophils, $\mathrm{T}_{\mathrm{H}} 1$ and $\mathrm{T}_{\mathrm{H}} 2$ cells, and airway epithelia. CCR 3 and CCR4 act as receptors for a variety of chemokines such as eotaxins and CCL5, which play a role in the pathogenesis of bronchial asthma [23]. There is evidence to suggest that CCR3 inhibition may decrease airway inflammation. CCR4 is believed to be able to recruit $\mathrm{T}_{\mathrm{H}} 2$ cells to the site of inflammation [24].

GW 766994 is a selective, competitively binding CCR3 antagonist that has already completed phase I trials in patients with mild to moderate asthma and high sputum eosinophilia [23]. Mogamulizumab (AMG 761) is a humanized monoclonal afucosylated anti-CCR4 IgG1 antibody [82]. It is currently in phase I trials, and no safety and efficiency data has yet been published.

GSK2239633 [N-(3-[(3-[5-chlorothiophene-2-sulfonamido]-4-methoxy-1H-indazol-1-yl)methyl]benzyl)2-hydroxy-2-methylpropanamide] is a potent CCR4 antagonist that acts by inhibiting CCR4-TARC (thymus and activation-regulated chemokine) binding and interrupting downstream signaling cascades [24]. The drug is currently in phase I trials. In an open-label study and a randomized clinical trial, GSK 2239633 significantly inhibited TARC from activating the CCR4 receptor [24].

\section{Drugs Targeting CRTH2 and CRTH2/DPR}

Chemoattractant receptor-homologous molecule expressed on $\mathrm{T}_{\mathrm{H}} 2$ cells (CRTH2) and D-type prostanoid receptor (DPR) are G-protein-coupled prostaglandin $\left(\mathrm{PGD}_{2}\right)$ receptors. $\mathrm{PGD}_{2}$ is secreted by mast cells during inflammation, including in asthma [83]. Binding of $\mathrm{PGD}_{2}$ 
to CRTH2 and DPR, respectively, mediates basophil, eosinophil, and $\mathrm{T}_{\mathrm{H}} 2$ cell chemotaxis, prolongs their survival [84], and stimulates the secretion of different cytokines [85]. Hence, potent CRTH2 and/or DPR antagonists might be a promising strategy in asthma treatment. Several encouraging antagonists are in different stages of development.

The two CRTH2 antagonists in phase I clinical trials are AM211 [(2'-[3-benzyl-1-ethyl-ureidomethyl]-6methoxy-4'-trifluoromethyl-biphenyl-3-yl)-acetic acid sodium salt] [86] and RG7185. To the date of reporting, three CRTH2 antagonists have been tested in phase II trials, i.e. NAV-QAV680, which showed good bioavailability in rats and rodents [87], setipiprant [2-(2-[1-naphthoyl]-8-fluoro-3,4-dihydro- $1 \mathrm{H}$-pyrido(4, 3-b)indol-5[2H]yl)acetic acid] [88], and ARRY-502.

Two CRTH2/DRP antagonists are also currently under clinical investigation. AMG853 showed no clinical efficacy in a phase II trial [89], while AZD1981 [4(acetylamino)-3-([4-chlorophenyl] thio)-2-methyl-1Hindole-1-acetic acid] is a new CRTH2/DPR antagonist in phase II clinical trials. To date, no data on its clinical and pharmaceutical properties have been published [90]. The major symptoms of aspirin-exacerbated respiratory disease (also termed Samter's triad) are nasal polyps, chronic hypertrophic eosinophilic sinusitis, and asthma. Aspirin and other nonsteroidal anti-inflammatory drugs are known to inhibit the cyclooxygenase-1 (COX-1) enzyme. Inhibition of the COX pathway may cause rhinitis, conjunctivitis, laryngospasm, and bronchospasm. This leads to a shift to increased leukotriene production, resulting in airway inflammation and bronchoconstriction. Under physiological conditions, $\mathrm{PGD}_{2}$ suppresses the release of histamines and prostaglandins from mast cells. In the presence of aspirin and other nonsteroidal anti-inflammatory drugs, the COX-1/PGD -induced inhibition of mast cell activation is diminished, which leads to the activation of mast cells, including the release of histamines and $\mathrm{PGD}_{2}$ [91]. As CRTH2/DRP antagonists, AMG853 and AZD1981 may be useful in the therapy of aspirininduced respiratory diseases.

\section{Drugs Targeting Epithelium-Derived Cytokines}

The epithelial cells that line mucosal surfaces not only act as a physical barrier but also participate in immune reactions. Small-airway epithelial cells produce different cytokines and thus affect $\mathrm{T}_{\mathrm{H}} 2$-mediated immune responses. TSLP, IL-25, and IL-33 represent a group of so-

Pharmacological Therapy of Bronchial Asthma called epithelial cell-derived cytokines. Treatment of patients with mild atopic asthma with the human anti-TSLP monoclonal immunoglobulin AMG 157 in a doubleblind, placebo-controlled study showed a decrease in allergen-induced bronchoconstriction [92]. In mice, antiIL-33 reduced airway inflammation and decreased airway remodeling [93]. IL-25 (also IL-17E) and its receptor were recently shown to be expressed on eosinophils from patients with allergic asthma [94]. Application of a monoclonal anti-IL-25 antibody in mice prevented AHR [95], and IL-25 may represent another promising drug target.

\section{Drugs Inhibiting Tyrosine Kinases}

Tyrosine kinases play a pivotal role in the course of asthma, especially in remodeling processes in lung tissue [96]. The activation of tyrosine kinases initiates a broad spectrum of downstream effector molecules and represents a promising target for drug treatment of asthma. A study in an animal model of asthma in guinea pigs showed encouraging results concerning the reduction of inflammatory effects of the broad-range protein tyrosine-kinase inhibitor genistein [97]. The use of imatinib, a tyrosine kinase inhibitor in a phase II trial, which is already approved for the treatment of chronic granulocytic leukemia, showed promising results in a mouse model for allergic airway inflammation concerning the prevention of inflammatory and remodeling events in lung tissue [98]. Another drug against chronic granulocyte leukemia that has already shown promising and even more positive effects than imatinib is nilotinib [99]. Clinical trials concerning safety and efficacy in asthma are yet to come.

\section{Drug Use for an Unapproved Indication}

In addition to guideline-driven treatment, some drugs have also been used to treat bronchial asthma as an unapproved indication.

Asthma patients are often also treated with macrolides (azithromycin, roxithromycin, and clarithromycin). Macrolides are often used as antibiotics to treat acute bacterial respiratory infections. There is growing evidence that macrolides not only exert an antibacterial effect but also modulate the immune system to improve inflammatory responses [100]. The long-term use of macrolides may improve several lung function parameters such as the $\mathrm{FEV}_{1}$ and the peak expiratory flow and decrease symptoms like AHR [101].

Int Arch Allergy Immunol 2015;168:241-252 DOI: $10.1159 / 000443930$ 
Cyclosporine is another off-label drug used to treat asthma. Cyclosporine is immunosuppressive by inhibiting T lymphocyte function [102] and avoiding the release of proinflammatory mediators by basophils and mast cells [103]. Specifically, it inhibits GM-CSF, IL-5, eotaxin, and bronchial eosinophilia [104]. Cyclosporine has been shown to improve several lung function parameters [105], but adverse side effects such as infection, hypertrichosis, tremor, and paraesthesia limit its use [102].

Methotrexate is an immunotherapy that inhibits the enzyme dihydrofolate reductase [103], IL-1, and basophilic histamine release [106]. Since no large-scale studies have been conducted to test its safety and efficacy, methotrexate use for the treatment of severe asthma remains controversial due to potentially severe side effects including a deranged liver function, disordered hematopoiesis, and infections that can ultimately lead to sepsis [107].

Azathioprine is another immunosuppressive agent that is used as an oral corticosteroid-sparing agent [108]. Azathioprine inhibits purine synthesis and thus inhibits lymphocyte proliferation [109]. However, there is only limited efficacy and safety data on azathioprine in the context of asthma, and more studies will need to be performed to evaluate its use in asthma. Likewise, interferon may also be a potent asthma treatment, particularly interferon- $\lambda$, which has been found to modulate the release of $\mathrm{T}_{\mathrm{H}} 1$ cytokines and activate $\mathrm{T}_{\mathrm{H}} 1$ pathway drift [110].

In general, these off-label drugs can disrupt hematopoiesis, derange liver enzymes, and lead to infections. The outcome of an off-labeled drug therapy is dependent on the individual and therapy is not always successful.

\section{Conclusion}

Bronchial asthma is a heterogeneous, complex, chronic inflammatory and obstructive disease with many different phenotypes. The recognition, identification, and characterization of $\mathrm{T}_{\mathrm{H}} 2$ and non- $\mathrm{T}_{\mathrm{H}} 2$ phenotypes have driven the development of molecular targeted therapies that are likely to become available in the near future. Many promising drugs are currently undergoing clinical trials that not only target the main IL but also receptors (such as chemokine receptors) and other signaling proteins. These are showing promise in meeting the ultimate goal of controlling severe, treatment-refractory asthma.

\section{References}

1 Dougherty RH, Fahy JV: Acute exacerbations of asthma: epidemiology, biology and the exacerbation-prone phenotype. Clin Exp Allergy 2009;39:193-202.

2 Wenzel SE: Asthma phenotypes: the evolution from clinical to molecular approaches. Nat Med 2012;18:716-725.

3 Custovic A, Johnston SL, Pavord I, et al: EAACI position statement on asthma exacerbations and severe asthma. Allergy 2013;68: 1520-1531.

4 D'Agostino B, Advenier C, De PR, et al: The involvement of sensory neuropeptides in airway hyper-responsiveness in rabbits sensitized and challenged to Parietaria judaica. Clin Exp Allergy 2002;32:472-479.

5 Pascual RM, Peters SP: Airway remodeling contributes to the progressive loss of lung function in asthma: an overview. J Allergy Clin Immunol 2005;116:477-486.

6 Loxham M, Davies DE, Blume C: Epithelial function and dysfunction in asthma. Clin Exp Allergy 2014;44:1299-1313.

7 Woodruff PG, Modrek B, Choy DF, et al: Thelper type 2-driven inflammation defines major subphenotypes of asthma. Am J Respir Crit Care Med 2009;180:388-395.

8 Duerr CU, McCarthy CD, Mindt BC, et al: Type I interferon restricts type 2 immunopathology through the regulation of group 2 in- nate lymphoid cells. Nat Immunol 2015;17: 65-75.

9 Lluis A, Ballenberger N, Illi S, et al: Regulation of T17 markers early in life through maternal farm exposure. J Allergy Clin Immunol 2014; 133:864-871.

10 Bouzigon E, Corda E, Aschard H, et al: Effect of $17 \mathrm{q} 21$ variants and smoking exposure in early-onset asthma. N Engl J Med 2008;359: 1985-1994.

11 Sokol CL, Barton GM, Farr AG, Medzhitov R: A mechanism for the initiation of allergeninduced T helper type 2 responses. Nat Immunol 2008;9:310-318.

12 Beier KC, Kallinich T, Hamelmann E: Master switches of T-cell activation and differentiation. Eur Respir J 2007;29:804-812.

13 Galli SJ, Tsai M: IgE and mast cells in allergic disease. Nat Med 2012;18:693-704.

14 Gould HJ, Sutton BJ: IgE in allergy and asthma today. Nat Rev Immunol 2008;8:205-217.

15 Rivera J, Gilfillan AM: Molecular regulation of mast cell activation. J Allergy Clin Immunol 2006; 117:1214-1225.

16 Veldhoen M, Uyttenhove C, Van SJ, et al: Transforming growth factor-beta 'reprograms' the differentiation of $\mathrm{T}$ helper 2 cells and promotes an interleukin 9-producing subset. Nat Immunol 2008;9:13411346.
17 Al-Ramli W, Prefontaine D, Chouiali F, et al $\mathrm{T}(\mathrm{H}) 17$-associated cytokines (IL-17A and IL$17 F)$ in severe asthma. J Allergy Clin Immunol 2009;123:1185-1187.

18 Naji N, Smith SG, Gauvreau GM, O’Byrne PM: T helper 17 cells and related cytokines after allergen inhalation challenge in allergic asthmatics. Int Arch Allergy Immunol 2014; 165:27-34.

19 Herbert C, Shadie AM, Kumar RK: Interleukin-17 signalling in a murine model of mild chronic asthma. Int Arch Allergy Immunol 2013;162:253-262.

20 Wang A, Wang Z, Cao Y, et al: CCL2/CCR2dependent recruitment of Th17 cells but not Tc17 cells to the lung in a murine asthma model. Int Arch Allergy Immunol 2015;166:52-62.

21 Barnes PJ: The cytokine network in asthma and chronic obstructive pulmonary disease. J Clin Invest 2008;118:3546-3556.

22 Zhou B, Comeau MR, De ST, et al: Thymic stromal lymphopoietin as a key initiator of allergic airway inflammation in mice. Nat Immunol 2005;6:1047-1053.

23 Neighbour H, Boulet LP, Lemiere C, et al: Safety and efficacy of an oral CCR3 antagonist in patients with asthma and eosinophilic bronchitis: a randomized, placebo-controlled clinical trial. Clin Exp Allergy 2014;44:508516. 
24 Cahn A, Hodgson S, Wilson R, et al: Safety, tolerability, pharmacokinetics and pharmacodynamics of GSK2239633, a CC-chemokine receptor 4 antagonist, in healthy male subjects: results from an open-label and from a randomised study. BMC Pharmacol Toxicol 2013;14:14.

25 Pelaia G, Vatrella A, Maselli R: The potential of biologics for the treatment of asthma. Nat Rev Drug Discov 2012;11:958-972.

26 Hamid Q, Tulic M: Immunobiology of asthma. Annu Rev Physiol 2009;71:489-507.

27 Lukacs NW, Strieter RM, Chensue SW, Widmer M, Kunkel SL: TNF-alpha mediates recruitment of neutrophils and eosinophils during airway inflammation. J Immunol 1995; 154:5411-5417.

28 Barnes PJ: Intrinsic asthma: not so different from allergic asthma but driven by superantigens? Clin Exp Allergy 2009;39:1145-1151.

29 Fitzpatrick AM, Teague WG, Meyers DA, et al: Heterogeneity of severe asthma in childhood: confirmation by cluster analysis of children in the National Institutes of Health/National Heart, Lung, and Blood Institute Severe Asthma Research Program. J Allergy Clin Immunol 2011;127:382-389.

30 Moore WC, Meyers DA, Wenzel SE, et al: Identification of asthma phenotypes using cluster analysis in the Severe Asthma Research Program. Am J Respir Crit Care Med 2010;181:315-323.

31 Molfino NA, Gossage D, Kolbeck R, Parker JM, Geba GP: Molecular and clinical rationale for therapeutic targeting of interleukin-5 and its receptor. Clin Exp Allergy 2012;42:712737.

32 Karjalainen EM, Laitinen A, Sue-Chu M, Altraja A, Bjermer L, Laitinen LA: Evidence of airway inflammation and remodeling in ski athletes with and without bronchial hyperresponsiveness to methacholine. Am J Respir Crit Care Med 2000;161:2086-2091.

33 Jatakanon A, Uasuf C, Maziak W, Lim S, Chung KF, Barnes PJ: Neutrophilic inflammation in severe persistent asthma. Am J Respir Crit Care Med 1999;160:1532-1539.

34 Laan M, Cui ZH, Hoshino H, et al: Neutrophil recruitment by human IL-17 via C-X-C chemokine release in the airways. J Immunol 1999; 162:2347-2352.

35 Platts-Mills TA: The role of immunoglobulin E in allergy and asthma. Am J Respir Crit Care Med 2001;164:S1-S5.

36 Chang TW: The pharmacological basis of antiIgE therapy. Nat Biotechnol 2000;18:157-162.

37 Takaku Y, Soma T, Nishihara F, et al: Omalizumab attenuates airway inflammation and interleukin-5 production by mononuclear cells in patients with severe allergic asthma. Int Arch Allergy Immunol 2013;161(suppl 2):107-117.

38 Hanania NA, Alpan O, Hamilos DL, et al: Omalizumab in severe allergic asthma inadequately controlled with standard therapy: a randomized trial. Ann Intern Med 2011;154: 573-582.
39 Chanez P, Contin-Bordes C, Garcia G, et al: Omalizumab-induced decrease of FceRI expression in patients with severe allergic asthma. Respir Med 2010;104:1608-1617.

40 Holgate S, Casale T, Wenzel S, Bousquet J, Deniz Y, Reisner C: The anti-inflammatory effects of omalizumab confirm the central role of IgE in allergic inflammation. J Allergy Clin Immunol 2005;115:459-465.

41 Vignola AM, Humbert M, Bousquet J, et al: Efficacy and tolerability of anti-immunoglobulin $\mathrm{E}$ therapy with omalizumab in patients with concomitant allergic asthma and persistent allergic rhinitis: SOLAR. Allergy 2004;59: 709-717.

42 Ali AK, Hartzema AG: Assessing the association between omalizumab and arteriothrombotic events through spontaneous adverse event reporting. J Asthma Allergy 2012;5:1-9.

43 Menzella F, Lusuardi M, Galeone C, Zucchi L: Tailored therapy for severe asthma. Multidiscip Respir Med 2015;10:1.

44 Arm JP, Bottoli I, Skerjanec A, et al: Pharmacokinetics, pharmacodynamics and safety of QGE031 (ligelizumab), a novel high-affinity anti-IgE antibody, in atopic subjects. Clin Exp Allergy 2014;44:1371-1385.

45 Rosenberg HF, Phipps S, Foster PS: Eosinophil trafficking in allergy and asthma. J Allergy Clin Immunol 2007;119:1303-1310.

46 Ogata N, Kouro T, Yamada A, et al: JAK2 and JAK1 constitutively associate with an interleukin-5 (IL-5) receptor alpha and betac subunit, respectively, and are activated upon IL-5 stimulation. Blood 1998;91:2264-2271.

47 Busse WW, Ring J, Huss-Marp J, Kahn JE: A review of treatment with mepolizumab, an anti-IL-5 mAb, in hypereosinophilic syndromes and asthma. J Allergy Clin Immunol 2010;125:803-813.

48 Haldar P, Brightling CE, Hargadon B, et al: Mepolizumab and exacerbations of refractory eosinophilic asthma. N Engl J Med 2009;360: 973-984.

49 Nair P, Pizzichini MM, Kjarsgaard M, et al: Mepolizumab for prednisone-dependent asthma with sputum eosinophilia. N Engl J Med 2009;360:985-993.

50 Roufosse FE, Kahn JE, Gleich GJ, et al: Longterm safety of mepolizumab for the treatment of hypereosinophilic syndromes. J Allergy Clin Immunol 2013;131:461-467.

51 Hambly N, Nair P: Monoclonal antibodies for the treatment of refractory asthma. Curr Opin Pulm Med 2014;20:87-94.

52 Walsh GM: Profile of reslizumab in eosinophilic disease and its potential in the treatment of poorly controlled eosinophilic asthma. Biologics 2013;7:7-11.

53 Busse WW, Katial R, Gossage D, et al: Safety profile, pharmacokinetics, and biologic activity of MEDI-563, an anti-IL-5 receptor alpha antibody, in a phase I study of subjects with mild asthma. J Allergy Clin Immunol 2010; 125:1237-1244
54 Laviolette M, Gossage DL, Gauvreau G, et al: Effects of benralizumab on airway eosinophils in asthmatic patients with sputum eosinophilia. J Allergy Clin Immunol 2013;132: 1086-1096.

55 Kolbeck R, Kozhich A, Koike M, et al: MEDI563, a humanized anti-IL-5 receptor alpha $\mathrm{mAb}$ with enhanced antibody-dependent cell-mediated cytotoxicity function. J Allergy Clin Immunol 2010;125:1344-1353.

56 Zhou Y, McLane M, Levitt RC: Th2 cytokines and asthma: interleukin-9 as a therapeutic target for asthma. Respir Res 2001;2:80-84.

57 Louahed J, Zhou Y, Maloy WL, et al: Interleukin 9 promotes influx and local maturation of eosinophils. Blood 2001;97:1035-1042.

58 Oh CK, Leigh R, McLaurin KK, Kim K, Hultquist M, Molfino NA: A randomized, controlled trial to evaluate the effect of an anti-interleukin-9 monoclonal antibody in adults with uncontrolled asthma. Respir Res 2013;14:93.

59 Parker JM, Oh CK, LaForce C, et al: Safety profile and clinical activity of multiple subcutaneous doses of MEDI-528, a humanized anti-interleukin-9 monoclonal antibody, in two randomized phase $2 \mathrm{a}$ studies in subjects with asthma. BMC Pulm Med 2011;11:14.

60 Punnonen J, de Vries JE: IL-13 induces proliferation, Ig isotype switching, and Ig synthesis by immature human fetal B cells. J Immunol 1994;152:1094-1102.

61 Punnonen J, Aversa G, Cocks BG, et al: Interleukin 13 induces interleukin 4-independent IgG4 and IgE synthesis and CD23 expression by human B cells. Proc Natl Acad Sci USA 1993;90:3730-3734.

62 Kaur D, Hollins F, Woodman L, et al: Mast cells express IL-13R alpha 1: IL-13 promotes human lung mast cell proliferation and Fc epsilon RI expression. Allergy 2006;61:10471053.

63 Risse PA, Jo T, Suarez F, et al: Interleukin-13 inhibits proliferation and enhances contractility of human airway smooth muscle cells without change in contractile phenotype. Am J Physiol Lung Cell Mol Physiol 2011; 300:L958-L966.

64 Horie S, Okubo Y, Hossain M, et al: Interleukin-13 but not interleukin-4 prolongs eosinophil survival and induces eosinophil chemotaxis. Intern Med 1997;36:179-185.

65 Munitz A, Brandt EB, Mingler M, Finkelman FD, Rothenberg ME: Distinct roles for IL-13 and IL-4 via IL-13 receptor alphal and the type II IL-4 receptor in asthma pathogenesis. Proc Natl Acad Sci USA 2008;105:7240-7245.

66 Walsh GM: Tralokinumab, an anti-IL-13 $\mathrm{mAb}$ for the potential treatment of asthma and COPD. Curr Opin Investig Drugs 2010; 11:1305-1312.

67 van HB, Nnane IP, Bouman-Thio E, et al Safety, tolerability and pharmacokinetics of a human anti-interleukin-13 monoclonal antibody (CNTO 5825) in an ascending singledose first-in-human study. Br J Clin Pharmacol 2013;75:1289-1298. 
68 Hodsman P, Ashman C, Cahn A, et al: A phase 1, randomized, placebo-controlled, dose-escalation study of an anti-IL-13 monoclonal antibody in healthy subjects and mild asthmatics. Br J Clin Pharmacol 2013;75:118128.

69 Long AA: Monoclonal antibodies and other biologic agents in the treatment of asthma. MAbs 2009;1:237-246.

70 Sempowski GD, Beckmann MP, Derdak S, Phipps RP: Subsets of murine lung fibroblasts express membrane-bound and soluble IL-4 receptors: role of IL-4 in enhancing fibroblast proliferation and collagen synthesis. J Immunol 1994;152:3606-3614.

71 Wenzel S, Ford L, Pearlman D, et al: Dupilumab in persistent asthma with elevated eosinophil levels. N Engl J Med 2013;368:24552466.

72 Burmeister GE, Fisher DM, Fuller R: Human pharmacokinetics/pharmacodynamics of an interleukin- 4 and interleukin-13 dual antagonist in asthma. J Clin Pharmacol 2009;49: 1025-1036.

73 Hart TK, Blackburn MN, Brigham-Burke M, et al: Preclinical efficacy and safety of pascolizumab (SB 240683): a humanized anti-interleukin-4 antibody with therapeutic potential in asthma. Clin Exp Immunol 2002;130:93100.

74 Steinke JW: Anti-interleukin-4 therapy. Immunol Allergy Clin North Am 2004;24:599614, vi.

75 Mir-Kasimov M, Sturrock A, McManus M, Paine R 3rd: Effect of alveolar epithelial cell plasticity on the regulation of GM-CSF expression. Am J Physiol Lung Cell Mol Physiol 2012;302:L504-L511.

76 Holgate ST, Roberts G, Arshad HS, Howarth $\mathrm{PH}$, Davies DE: The role of the airway epithelium and its interaction with environmental factors in asthma pathogenesis. Proc Am Thorac Soc 2009;6:655-659.

77 Krinner EM, Raum T, Petsch S, et al: A human monoclonal IgG1 potently neutralizing the pro-inflammatory cytokine GM-CSF. Mol Immunol 2007:44:916-925.

78 Erin EM, Leaker BR, Nicholson GC, et al: The effects of a monoclonal antibody directed against tumor necrosis factor-alpha in asthma. Am J Respir Crit Care Med 2006;174: 753-762.

79 Holgate ST, Noonan M, Chanez P, et al: Efficacy and safety of etanercept in moderate-tosevere asthma: a randomised, controlled trial. Eur Respir J 2011;37:1352-1359.

80 Wenzel SE, Barnes PJ, Bleecker ER, et al: A randomized, double-blind, placebo-controlled study of tumor necrosis factor-alpha blockade in severe persistent asthma. Am J Respir Crit Care Med 2009;179:549-558.

81 Alkhouri H, Moir LM, Armour CL, Hughes JM: CXCL1 is a negative regulator of mast cell chemotaxis to airway smooth muscle cell products in vitro. Clin Exp Allergy 2014;44: 381-392.
82 Subramaniam JM, Whiteside G, McKeage K, Croxtall JC: Mogamulizumab: first global approval. Drugs 2012;72:1293-1298.

83 Arima M, Fukuda T: Prostaglandin $\mathrm{D}(2)$ and $\mathrm{T}(\mathrm{H}) 2$ inflammation in the pathogenesis of bronchial asthma. Korean J Intern Med 2011; 26:8-18.

84 Schuligoi R, Sturm E, Luschnig P, et al CRTH2 and D-type prostanoid receptor antagonists as novel therapeutic agents for inflammatory diseases. Pharmacology 2010;85: 372-382.

85 Kostenis E, Ulven T: Emerging roles of DP and CRTH2 in allergic inflammation. Trends Mol Med 2006;12:148-158.

86 Bain G, King CD, Brittain J, et al: Pharmacodynamics, pharmacokinetics, and safety of AM211: a novel and potent antagonist of the prostaglandin D2 receptor type 2. J Clin Pharmacol 2012;52:1482-1493.

87 Sandham DA, Arnold N, Aschauer H, et al: Discovery and characterization of NVPQAV680, a potent and selective CRTh2 receptor antagonist suitable for clinical testing in allergic diseases. Bioorg Med Chem 2013; 21:6582-6591.

88 Fretz H, Valdenaire A, Pothier J, et al: Identification of 2-[2-(1-naphthoyl)-8-fluoro-3,4dihydro-1H-pyrido(4, 3-b)indol-5(2H)-yl] acetic acid (setipiprant/ACT-129968), a potent, selective, and orally bioavailable chemoattractant receptor-homologous molecule expressed on Th2 cells (CRTH2) antagonist. J Med Chem 2013;56:4899-4911.

89 Busse WW, Wenzel SE, Meltzer EO, et al: Safety and efficacy of the prostaglandin D2 receptor antagonist AMG 853 in asthmatic patients. J Allergy Clin Immunol 2013;131:339345.

90 Schmidt JA, Bell FM, Akam E, et al: Biochemical and pharmacological characterization of AZD1981, an orally available selective DP2 antagonist in clinical development for asthma. Br J Pharmacol 2013;168:1626-1638.

91 Fischer AR, Rosenberg MA, Lilly CM, et al: Direct evidence for a role of the mast cell in the nasal response to aspirin in aspirin-sensitive asthma. J Allergy Clin Immunol 1994;94: 1046-1056.

92 Gauvreau GM, O’Byrne PM, Boulet LP, et al: Effects of an anti-TSLP antibody on allergeninduced asthmatic responses. N Engl J Med 2014;370:2102-2110.

93 Mizutani N, Nabe T, Yoshino S: Interleukin-33 and alveolar macrophages contribute to the mechanisms underlying the exacerbation of IgE-mediated airway inflammation and remodelling in mice. Immunology 2013; 139:205-218.

94 Tang W, Smith SG, Beaudin S, et al: IL-25 and IL-25 receptor expression on eosinophils from subjects with allergic asthma. Int Arch Allergy Immunol 2014;163:5-10.
95 Ballantyne SJ, Barlow JL, Jolin HE, et al: Blocking IL-25 prevents airway hyperresponsiveness in allergic asthma. J Allergy Clin Immunol 2007;120:1324-1331.

96 Wong WS: Inhibitors of the tyrosine kinase signaling cascade for asthma. Curr Opin Pharmacol 2005;5:264-271.

97 Duan W, Kuo IC, Selvarajan S, Chua KY, Bay BH, Wong WS: Antiinflammatory effects of genistein, a tyrosine kinase inhibitor, on a guinea pig model of asthma. Am J Respir Crit Care Med 2003;167:185-192.

98 Rhee CK, Kim JW, Park CK, et al: Effect of imatinib on airway smooth muscle thickening in a murine model of chronic asthma. Int Arch Allergy Immunol 2011;155:243251.

99 Rhee CK, Kang JY, Park CK, et al: Effect of nilotinib on airway remodeling in a murine model of chronic asthma. Exp Lung Res 2014;40:199-210

100 Tamaoki J, Kadota J, Takizawa H: Clinical implications of the immunomodulatory effects of macrolides. Am J Med 2004; 117(suppl 9A):5S-11S.

101 Tong X, Guo T, Liu S, et al: Macrolide antibiotics for treatment of asthma in adults: a meta-analysis of 18 randomized controlled clinical studies. Pulm Pharmacol Ther 2014; 31:99-108.

102 Alexander AG, Barnes NC, Kay AB: Trial of cyclosporin in corticosteroid-dependent chronic severe asthma. Lancet 1992;339: 324-328.

103 Mathew J, Aronow WS, Chandy D: Therapeutic options for severe asthma. Arch Med Sci 2012;8:589-597.

104 Khan LN, Kon OM, MacFarlane AJ, et al Attenuation of the allergen-induced late asthmatic reaction by cyclosporin $\mathrm{A}$ is associated with inhibition of bronchial eosinophils, interleukin-5, granulocyte macrophage colony-stimulating factor, and eotaxin. Am J Respir Crit Care Med 2000;162: 1377-1382.

105 Coren ME, Rosenthal M, Bush A: The use of cyclosporin in corticosteroid dependent asthma. Arch Dis Child 1997;77:522-523.

106 Calderon E, Coffey RG, Lockey RF: Methotrexate in bronchial asthma. J Allergy Clin Immunol 1991;88:274-276.

107 Attar SM: Adverse effects of low dose methotrexate in rheumatoid arthritis patients: a hospital-based study. Saudi Med J 2010;31: 909-915.

108 Dean T, Dewey A, Bara A, Lasserson TJ, Walters EH: Azathioprine as an oral corticosteroid sparing agent for asthma. Cochrane Database Syst Rev 2004;CD003270.

109 Sahasranaman S, Howard D, Roy S: Clinical pharmacology and pharmacogenetics of thiopurines. Eur J Clin Pharmacol 2008;64: 753-767.

110 Koch S, Finotto S: Role of interferon-lambda in allergic asthma. J Innate Immun 2015; 7:224-230. 